\title{
TRUST AS A PREDICTOR OF OPTIMAL PERSONALITY FUNCTIONING
}

\author{
Grankina-Sazonova N. V. \\ V. N. Karazin Kharkiv National University, Svobody Square, 6, Kharkiv, Ukraine \\ E-mail: natalia.grankina85@gmail.com, https://orcid.org/0000-0002-0818-572X
}

Received 22 September 2018

In the study the problem of optimal personality functioning is regarded. The theoretical background of the OPF in different approaches shows that the existing a general understanding of OPF is too wide and more concrete approaches to it include different components regarding the views of the authors to the personality. The humanistic approach to the personality views OPF in terms of personal growth, self-actualization, autonomy, values and goals. The model of OPF, consisting of two domains, is proposed. These domains are C. Ryff's model of psychological well-being and S. Maddi's hardiness. Both constructs grew out of humanistic views on human nature and have theoretical and empirical background. Trust is regarded as an important predictor of OPF. Despite the existing personality development theories, which postulate that trust is the basic disposition for personality functioning and it influences its interactions with the world, we observe the lack of empirical studies devoted to trust as a well-being or OPF predictor. The empirical study of indexes of OPF (consisting of PWB and hardiness) and trust at the sample of students was provided. The data of correlation analysis, regression analysis and structural modelling empirically confirm the validity of model of OPF, including domains of PWB and Hardiness. We also provide the evidence of importance of general trust and self-trust for OPF.

KEY WORDS: optimal personality functioning, trust, psychological well-being, hardiness

\section{ДОВІРА ЯК ПРЕДИКТОР ОПТИМАЛЬНОГО ФУНКЦІОНУВАННЯ ОСОБИСТОСТІ}

Гранкіна-Сазонова Н. В. Харківський національний університет імені В. Н. Каразіна, площса Свободи, 6, м. Харків, Україна

В даній статті розглядається проблема оптимального функціонування (ОФ) особистості як сучасний підхід, який грунтується на його розумінні як окремого формування, а не відсутності захворювань. Хоча існує загальне визначення оптимального функціонування, яке розділяється різними напрямками до його розуміння, конкретні складові ОФ в різних психологічних школах відрізняються. Розуміння ОФ варіює від приємного емоційно стану до служіння особистості вищим цілям та добробуту суспільства. Виникає необхідність формування більш чіткої моделі ОФ для реалізації задач його емпіричного дослідження. В рамках гуманістичного підходу необхідними складовими ОФ є особистісний ріст, прагнення самоактуалізації та вищих цінностей, автономія, наявність цілей та сенсу у житті. Евдемоністичний підхід до психологічного благополуччя також грунтується на цих засадах. Саме тому нами пропонується долучити модель психологічного благополуччя К. Ріфф до моделі ОФ в якості одного з доменів. Ця модель містить в собі всі найчастіше згадувані представниками гуманістичної психології диспозиції ОФ особистості. В якості другого домену пропонується долучити життєстійкість С. Мадді як патерн диспозицій, які дозволяють особистості в ситуаціях стресів не просо переживати труднощі, а й особистісно зростати завдяки їх подоланню. Життєстійкість додає психологічному благополуччю стійкості в складних умовах та сил для евдемоністичного способу життя. Крім того, пропонується розглядати довіру та іiі види - довіру до світу, довіру до інших людей та довіру до себе - в якості важливого предиктора ОФ особистості. Хоча існують теоретичні уявлення про важливість довіри для формування та функціонування особистості, емпіричних досліджень, що підтверджують це значення спостерігається замало.

В статті наведено результати емпіричного дослідження показників оптимального функціонування та довіри. Дані кореляційного аналізу, регресійного аналізу та структурного моделювання підтверджують свідчать про те, що довіра, особливо загальна довіра та довіра до себе, $є$ вагомим предиктором ОФ особистості. Також наведено емпіричне обгрунтування доцільності об'єднання психологічного благополуччя та життєстійкості в латентну змінну оптимального функціонування.

КЛЮЧОВІ СЛОВА: оптимальне функціонування особистості, психологічне благополуччя, життєстійкість, довіра.

\section{INTRODUCTION}

The problem of optimal personal functioning (OPF) is widely discussed and examined since the humanistic psychologists and some researches who forwarded them paid attention, that the absence of illness doesn`t make a person nor happy neither healthy in a wide meaning (H. Allport, W. James, A. Maslow, C. Rogers, M. Yahoda et al.). The humanistic approach to OPF is known in terms of A. Maslow's selfactualization, C. Rogers` fully functioning person etc. "According to Bugental, one of the basic postulates of 
humanistic psychology is that human beings are intentional, goal-oriented, and they are motivated to seek meaning and value" [19, p.132].

Leong and Wong also mention some other approaches to the problem of OPF [19]. One is the performance-based approach: when optimal functioning is understood as performing by the person all its best, using all its resources to provide the best result. But it's not possible to perform all your best all the time, it would be rather exhausting.

One more approach is White's competence model, where competence is understood as "an organism`s capacity to interact effectively with its environment" (cit. after [19, p.132]). This competence is expected in personal development and spiritual enlightenment, competence in artistic endeavors, and competence in maintaining interpersonal relationships and group harmony.

Competence is also regarded as one of the basic needs in modern Self-Determination Theory by E. Deci and R. Ryan [12]. The authors provide their own view to OPF, which depends on satisfaction of some specific needs, but in general, their theory is related to humanistic approach to the personality.

M. Seligman`s Positive Psychology is totally devoted to the study of positive functioning, positive feelings, good life and human strengths [16]. For M. Seligman positive functioning is synonymous to happiness. Other terms, widely used to describe OPF are life-satisfaction, subjective well-being (E. Diener) and psychological well-being (C. Ryff). The hedonic approach to well-being (N. Bradburn, E. Diener) regards it mostly as the prevalence of positive affects over negative and satisfaction of needs. The eudemonic approach (E. Deci, R. Ryan, C. Ryff) stand on the humanistic basis and see it in terms of personal growth, higher values, autonomy and connectedness to other people.

We can find such definitions of OPF as "an area of study that focuses on understanding how individuals become the best that they can be as well as how they may achieve their personal potentials" [8] or "optimizing health, mental, physical, emotional and spiritual functioning, and peak performance fields" [3]. However, they are too much general and don't give us any concrete understanding of what OPF is, in the end.

Therefore, we see the need to make the construct of OPF more defined and operationalized. Regarding the existing approaches to the problem of OPF we propose to examine it as the association of two domains: C. Ryff"s model of psychological well-being (PWB) and S. Maddi's hardiness.

The C. Ryff"s model of PWB has a theoretical background and empirical confirmation. It is based on M. Yahoda's model of mental health and humanistic psychologists' approaches to a personality and represents the conclusion of all most often acknowledged dimensions of optimally functioning personality: Personal growth, Purpose in life, Autonomy, Positive relations with others, Self-acceptance and Environmental mastery. It is also important that these factors are seen as dispositions and dimensions, not as fixed result, as far as life's going on all the time [13].

At the same time, the model of C. Ryff doesn't include a dimension which would help the personality to stand stresses and difficulties in life. A person needs some capacities and resources to survive in difficult situation, and, also such resources are needed to provide eudemonic well-being, as far as it requires the overcoming of just a pleasant life temptation. We think that hardiness may become such factor.

$\mathrm{S}$. Maddi's hardiness is a set of dispositions which help the person to see the difficulties as a challenge and a possibility for own personal growth. S. Maddi also comes out of humanistic and existential paradigms in his theoretical background of hardiness. And the main idea of hardiness is the personal growth in stressful conditions and living a mindful life [9].

In this way, we think that PWB and hardiness can be regarded as two domains of OPF and make up its model.

Other important questions about OPF are as follows: what factors do influence it the most and what can psychology do to help people in its reaching? The second question is especially important for practical psychologists and psychotherapists who meet patients with moderate or high social and economic status, but 
low PWB, feeling unhappy.

Different factors and traits are examined and supposed to be antecedents of well-being, such as locus of control, optimism, neuroticism, perfectionism, self-esteem, self-efficacy and others $[10 ; 14 ; 20]$. The review of the studies show, that age, gender and external circumstances are more neutral in influencing wellbeing and OPF, than personal traits [14].

We would like to pay attention to trust as an important predictor of OPF. From the one hand, the meaning of trust for the optimal development of the personality and for the optimal functioning is widely known in terms of E. Erikson's epigenetic theory. E. Erikson found, that the formation of trust or distrust to the world, to other people and to oneself in early childhood influences all further personality development and functioning. A. Maslow, C. Rogers, S. Jourard mentioned the importance of self-disclosure for OPF, which is impossible without trust. Trust is considered to be necessary for psychotherapeutic relations and effectiveness of psychotherapy and psychological counselling (C. Rogers, F. Perls, I. Yalom et al.). L. Marcher and E. Yarlnes also regard forming of trust in early childhood as an important stage of personal development, which influences all the further life. T. Skripkina focuses trust as the basic condition of interaction of the personality with the world and underlines the outstanding meaning of trust to the world and self-trust for person's well-being and activity [17].

At the same time we can observe the lack of empirical investigations, devoted to trust in the clue of personality functioning. There exist a wide range of studies, devoted to social trust in its different manifestations and spheres of social life. However, according to T. Skripkina, trust to other people is just one separate case of trust to the world, and these studies do not consider the phenomenon of trust in deeper personality perspective.

Therefore, though we have deep theoretical basis for regarding trust as an important condition of OPF, we have lack of empirical studies devoted to this problem. The investigations, which refer to trust as a predictor of well-being, confirm the positive connection of these factors [2], but trust is mostly regarded in its social representation in different forms. The wider view to trust as a predictor of OPF we can find in study of Christie and our studies together with I. Kryazh [1; 4-6].

In that way, we can state the lack of empirical studies devoted to trust as an important predictor of OPF though we have a rich theoretical background for viewing it in this way.

The aims of the article:

1. To give the theoretical background and empirical confirmation of the association of psychological well-being (PWB) and hardiness in terms of the Optimal Personality Functioning (OPF) construct.

2. To investigate the links between trust (and its kinds) and indexes of OPF.

Materials and Methods. Optimal Personality Functioning was measured by C. Ryff's 'Psychological Wellbeing Scale'(PWB) and S. Maddi`s 'Hardiness Survey' in modification of E. Osin and E. Rasskazova, 24 points version [11]. PWB consists of six dimensions: Positive relations with other people, Autonomy, Personal Growth, Environmental mastering, Self-acceptance and Purpose in life. Hardiness also includes three scales: Commitment, Control, Challenge.

To measure trust we used two tests: A. V. Kupreichenko`s 'Methodic of examining trust/distrust to the world, to other people and to oneself' and T. P. Skripkina's 'Reflexive questionnaire of level of selftrust' (will be referred further as RST) [7].

The data processing was provided by the methods of statistical analysis, such as correlation analysis, hierarchical regression analysis, and structural equation modeling (SEM). The received structural models were verified in the module SEPATH, using method of estimation ADF Gramian, as this method is recommended in cases, when we observe the data deviation from normal distribution [15; 18]. Statistical analysis was fulfilled in the program Statistica 6. 


\section{Sample and procedure.}

The sample of the study consists of the students of N. V. Karazin Kharkiv National University (KNU) and Kharkiv National Pharmaceutical University (KNPU). The age of the respondents ranges from 17 to 25 years (the median is 22). The students of four departments took part in the research. These departments are Faculty of Psychology, Historical Faculty, Faculty of Physics and Energetics (KNU) and Faculty of Laboratory Diagnostics (KNPU). More detailed characteristics of the sample are provided in Table 1.

Table 1

Characteristics of the sample

\begin{tabular}{|l|c|c|c|}
\hline \multicolumn{1}{|c|}{ Specialty } & Female & Male & General \\
\hline Faculty of Psychology & $89(39,9 \%)$ & $10(5,2 \%)$ & $99(45,1 \%)$ \\
\hline $\begin{array}{l}\text { Faculty of Physics and } \\
\text { Energetics }\end{array}$ & $8(3,8 \%)$ & $24(11,3 \%)$ & $32(15 \%)$ \\
\hline Historical Faculty & $20(9,4 \%)$ & $13(6,1 \%)$ & $33(15,5 \%)$ \\
\hline $\begin{array}{l}\text { Faculty of Laboratory } \\
\text { Diagnostics }\end{array}$ & $44(20,7 \%)$ & $8(3,7 \%)$ & $52(24,4)$ \\
\hline \multicolumn{1}{|c|}{$\Sigma$} & $159(73,7 \%)$ & $57(26,3 \%)$ & 216 \\
\hline
\end{tabular}

The testing was held in groups of approximately 15 people in each.

\section{RESULTS}

The data of descriptive statistics (median, mean and standard deviation) for all examined indexes is shown in the Table 2.

Table 2

Descriptive statistics

\begin{tabular}{|l|r|r|r|r|}
\hline Variable & Valid N & \multicolumn{1}{|c|}{ Mean } & Median & \multicolumn{1}{|c|}{ Std.Dev. } \\
\hline Trust & 216 & 15,90 & 16,00 & 6,22 \\
\hline Trust to other people & 216 & $-3,70$ & $-4,00$ & 3,26 \\
\hline Trust to the world & 216 & $-3,91$ & $-4,00$ & 2,41 \\
\hline Self-trust & 216 & 23,51 & 24,00 & 3,05 \\
\hline RST & 216 & 4,92 & 5,00 & 0,60 \\
\hline Hardiness & 216 & 43,16 & 44,00 & 12,05 \\
\hline Commitment & 216 & 18,50 & 19,00 & 5,75 \\
\hline Control & 216 & 14,34 & 14,00 & 4,28 \\
\hline Challenge & 216 & 10,32 & 11,00 & 3,34 \\
\hline PWB & 216 & 356,12 & 359,00 & 43,80 \\
\hline Positive relationships with other people & 216 & 59,12 & 59,00 & 10,22 \\
\hline Autonomy & 216 & 56,82 & 57,00 & 9,26 \\
\hline Environmental mastering & 216 & 56,02 & 57,00 & 8,79 \\
\hline Personal Growth & 216 & 64,72 & 66,00 & 9,07 \\
\hline Purpose in life & 216 & 62,09 & 63,00 & 10,08 \\
\hline Self-acceptance & 216 & 57,35 & 58,00 & 10,80 \\
\hline
\end{tabular}

The distribution analysis results evidence that all the scales of Hardiness (Commitment, Challenge, Control and Hardiness index), some scales of PWB (Personal growth, Purpose in life, Self-acceptance), 
indexes of trust to the world, trust to other people and both indexes of self-trust significantly dismiss the normal distribution. Consequently, we used nonparametric statistical methods for the further data analysis, which are not sensitive to violations of normal distribution.

Results of correlation analysis. The correlation analysis between indexes of PWB, Hardiness and trust was carried out. The results of correlation analysis are presented in table 3 .

As we can see in the table, the indexes of PWB and hardiness are highly related to the indexes of general trust and different kinds of trust. The most significant connections we observe for general trust index and self-trust. All the kinds of trust appear to be connected to all scales of Hardiness and PWB, except connection between Trust to other people and Autonomy, which occur to be independent one of another. As far as autonomy means being independent on other people's thought and capacity to stand the social pressure in own view, the absence of the connection between these two variables seems to be theoretically grounded.

In general we can state a strong connection between trust and OPF.

Table 3

The results of correlation analysis between indexes of OPF and trust

\begin{tabular}{|l|l|l|l|l|l|}
\hline Variable & Trust & $\begin{array}{c}\text { Trust to } \\
\text { the world }\end{array}$ & $\begin{array}{c}\text { Trust to } \\
\text { other } \\
\text { people }\end{array}$ & Self-trust & \multicolumn{1}{|c|}{$\begin{array}{c}\text { RST } \\
\text { (Self- } \\
\text { Trust) }\end{array}$} \\
\hline PWB & 0,52 & 0,38 & 0,28 & 0,47 & 0,56 \\
\hline Positive relationships with others & 0,4 & 0,28 & 0,35 & 0,23 & 0,42 \\
\hline Autonomy & 0,24 & $0,16^{*}$ & - & 0,37 & 0,3 \\
\hline Environmental mastering & 0,47 & 0,33 & 0,26 & 0,44 & 0,54 \\
\hline Personal Growth & $0,38^{* *}$ & 0,32 & $0,19^{* *}$ & 0,34 & 0,32 \\
\hline Purpose in life & 0,44 & 0,36 & 0,26 & 0,34 & 0,49 \\
\hline Self-acceptance & 0,48 & 0,34 & 0,23 & 0,47 & 0,52 \\
\hline Hardiness & 0,53 & 0,35 & 0,36 & 0,41 & 0,6 \\
\hline Commitment & 0,48 & 0,33 & 0,33 & 0,37 & 0,59 \\
\hline Control & 0,46 & 0,29 & 0,28 & 0,42 & 0,49 \\
\hline Challenge & 0,5 & 0,34 & 0,37 & 0,33 & 0,51 \\
\hline
\end{tabular}

$\mathrm{p}<0,001$, except $* \mathrm{p}<0,05 ; * * \mathrm{p}<0,005$

Hierarchical regression analysis of data. The data received due to correlation analysis let us judge on the existence of connections between variables and the significance of the found connections. However, it doesn't answer us the question what relations have these variables, if one of them causes the others. This information we can receive using the methods of multiple regression.

The methods of multiple regression make it possible to evaluate the measure of connection of more than two variables. The multiple regression also allows to identify partial correlations. It can show us which of the variables can be the predictors for the dependable variable. In our study, we can check the causal effect of trust and its different kinds on the indexes of OPF: PWB and Hardiness.

Thus, taking into account the results of correlation analysis, we built and checked the regression models of PWB and Hardiness as the dependent variables. Different kinds of trust were supposed to be the predictors in these models. The verification of these regression models was carried out by the Forward Stepwise method: the selection of the most significant predictors is held until 'the best' regression model is received. The results of regression modelling are represented in the table 4.

The data of regression modelling show, that the trust is a quite strong predictor both for PWB and for Hardiness. Self-trust and general trust indexes explain PWB at the level of $45 \%$ and hardiness at the level of $47 \%$. These results are rather significant.

In the case when we include in the model different kinds of trust - trust to the world, trust to other 
people, self-trust and RST - we find, that all of them explain hardiness at the rate of $46 \%$. At the same time trust to other people appears to be excluded from the model of PWB, and all the others kinds of trust predict PWB at the rate of $46,5 \%$.

The most important predictor in all our regression models appears to be RST.

Thus, we can state, that trust is an important factor, which significantly influence the OPF. The most important role in predicting OPF has Self-Trust as a "specific human's relation to its inner world, to its subjectivity as a value" [17, p.126]. That is, a significant factor of personality`s PWB and hardiness is its own relation to its inner, subjective reality as to valuable and important.

Table 4

Summary of regression analysis for PWB and Hardiness

\begin{tabular}{|c|c|c|c|c|}
\hline \multirow{3}{*}{$\begin{array}{l}\text { Variables- } \\
\text { predictors, put to } \\
\text { the analysis }\end{array}$} & \multicolumn{4}{|c|}{ Dependent variable } \\
\hline & \multicolumn{2}{|l|}{ PWB } & \multicolumn{2}{|c|}{ Hardiness } \\
\hline & $\begin{array}{c}\text { Predictors with } \beta \text { - } \\
\text { coefficients, left in the } \\
\text { model }\end{array}$ & $\mathrm{R}^{2}$ and $\mathrm{R}^{2} \mathrm{adj}$ & $\begin{array}{c}\text { Predictors with } \beta \text { - } \\
\text { coefficients, left in the } \\
\text { model }\end{array}$ & $\mathrm{R}^{2}$ and $\mathrm{R}^{2} \mathrm{adj}$ \\
\hline $\begin{array}{l}\text { Trust to other } \\
\text { people, Trust to } \\
\text { the world, Self- } \\
\text { trust, RST }\end{array}$ & $\begin{array}{l}\text { RST } 0,41 ; \\
\text { Trust to the world } 0,19 ; \\
\text { Self-trust } 0,23\end{array}$ & $\begin{array}{c}\mathrm{R}^{2} 0,47 ; \mathrm{R}^{2} \mathrm{adj} \\
0,465\end{array}$ & $\begin{array}{c}\text { RST } 0,47 ; \\
\text { Trust to other people } \\
0,19 ; \\
\text { Trust to the world } \\
0,14^{*} ; \\
\text { Self-trust } 0,13^{*}\end{array}$ & $\begin{array}{c}\mathrm{R}^{2} 0,47 ; \\
\mathrm{R}^{2} \text { adj } 0,46\end{array}$ \\
\hline $\begin{array}{l}\text { Trust (general } \\
\text { index) and RST }\end{array}$ & $\begin{array}{l}\text { RST } 0,44 \text {; } \\
\text { Trust } 0,35\end{array}$ & $\begin{array}{c}\mathrm{R}^{2} 0,46 ; \mathrm{R}^{2} \mathrm{adj} \\
0,45\end{array}$ & Trust 0,$46 ;$ RST 0,34 & $\begin{array}{c}\mathrm{R}^{2} 0,47 \\
\mathrm{R}^{2} \text { adj } 0,47\end{array}$ \\
\hline
\end{tabular}

The indexes are significant at the level $\mathrm{p}<0,001$, besides * $\mathrm{p}<0,05$

Verification of structural model. Regarding the results of correlation and regression analysis and the hypothesis that OPF consists of two domains (PWB and hardiness), we built and revised the structural model of OPF with latent variables "Trust" (includes general index of trust and reflexive Self-Trust - RST) and "OPF" (consists of two manifest variables PWB and Hardiness). The model is represented in the fig.1.

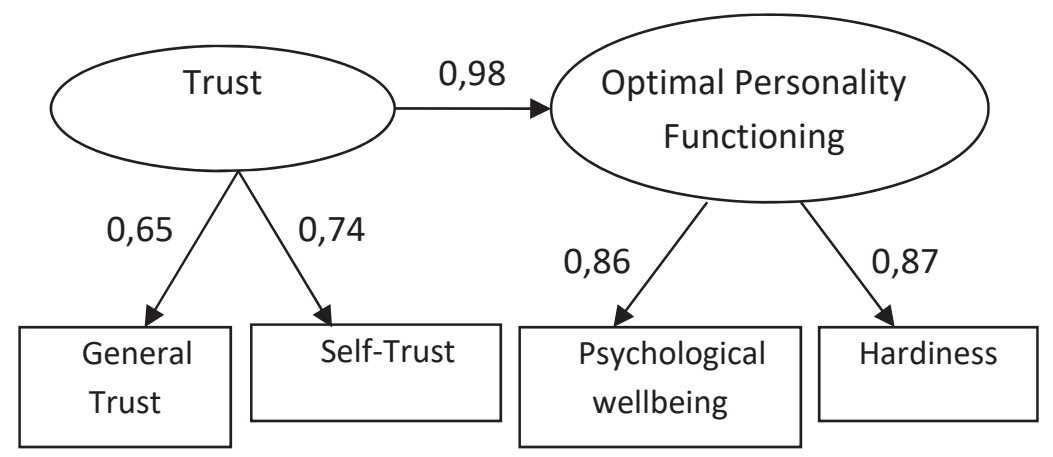

Fig. 1. Structural model, describing connections of trust and OPF (relations are significant with $\mathrm{p}<0.001$ ). Fitness indexes: $\chi 2 / \mathrm{df}=0,061 / 1 ; \mathrm{p}=0,8$; RMSEA 0,002; GFI 1; AGFI 0,998

The fitness indicators of the model were calculated in module SEPATH by method of estimation ADF Gramian, as far as it is recommended in cases of deviation of the data from normal distribution. All the fitness indicators have meanings, which confirm the model. We provide five of them - statistics $\chi 2$, df, RMSEA, GFI and AGFI.

Conclusions. The provided study affirms the theoretical background about the important role of trust for OPF. Trust has different dimensions: trust to the world, trust to other people and self-trust. All of them play their role for OPF, but all of them may be joint in one latent variable "Trust". At the same time, the regression analysis showed that self-trust has a distinctively important meaning for PWB as a domain of 
OPF.

The provided empirical study confirmed the theoretical grounding for association of hardiness and psychological well-being in a framework of optimal functioning construct.

In that way, we regard two separate formations - Trust and OPF. Trust is an independent phenomenon, which has its own components, and trust is a strong predictor of OPF.

The important role of trust and self-trust as its separate kind should be mentioned in practice of counselling psychology and psychotherapy: providing lacking trust in the counselling process may influence up to half of general efficacy.

\section{REFERENCES}

1. Christie A.M.H., Jordan P.J., Troth A.C. (2015) Trust antecedents: emotional intelligence and perceptions of others, International Journal of Organizational Analysis, Vol. 23 Issue: 1, pp.89-101, https://doi.org/10.1108/IJOA07-2013-0695

2. Helliwell J.F., Wang S. (2011). Trust and wellbeing. International Journal of Wellbeing, 1(1), 42-78. doi:10.5502/ijw.v1i1.9

3. https://www.aapb.org/i4a/pages/index.cfm?pageID=3641\&activateFull=true

4. Kryazh, I., Grankina-Sazonova, N. (2018). Mediating role of trust between emotional intelligence and positive functioning of personality. Fundamental and applied researches in practice of leading scientific schools, 26 (2), 326-334.

5. Kryazh I.V., Grankina-Sazonova N.V. (2017) Trust and emotional intelligence as psychology students` personal wellbeing. Psychology: reality and perspektives: scientific studies series of Rivne State Humanitarian University. Iss.8. - p. 137-143 [in Ukrainian]

6. Kryazh I. I., Levenets N. V. (2018) Trust and Emotional Intelligence as Predictors of Subjective Wellbeing of Students. Messenger of V. N. Karazin Kharkiv National University. Series: "Psychology". Vol. 64. [in Ukrainian]

7. Kupreichenko A. B. (2008) Psychology of Trust and Distrust. M: Publisher "Institute of Psychology RAN". 564p.

8. Levesque R.J.R. (2011) Optimal Functioning. In: Levesque R.J.R. (eds) Encyclopedia of Adolescence. Springer, New York, N.Y.

9. Maddi S. R. (2002) The Story of Hardiness: Twenty Years of Theorising, Research and Practice- Consulting Psychology Journal: Practice and Research - Vol.54 - No3 - p.175-185. DOI:10.1037//1061-4087.54.3.175

10. Malkina-Pykh I. G. (2014) Predicting and increasing subjective well-being: response function model and rhythmic movement therapy. Report on the 28th Conference of the European Society of Health Psychology "Beyond prevention and intervention: increasing well-being" 26 - 30 August, 2014, Innsbruck, Austria. DOI: 10.13140/2.1.4118.0968

11. Osin E. N., Rasskazova E.I. (2013) Short version of hardiness test: psychometrical characteristics and providing in organizational context. Messenger of Moscow University. Series 14. Psychology. Iss. 2. 147-165 [in Russian].

12. Ryan M. R., Huta V., Deci E. L. (2008) Living Well: a Self-Determination Theory Perspective on Eudaimonia. Journal of Happiness Studies. - 9:139-170. DOI: 10.1007/s10902-006-9023-4

13. Ryff C. D. (1989) Happiness is everything or is it? Explorations on the meaning of psychological well-being. Journal of Personality and Social Psychology. - Vol.57. - No.6. - P.1069-1081

14. Satterfield, J. M. (2001). Happiness, excellence, and optimal human functioning: Review of a special issue of the American Psychologist(2000;55:5-183), Martin E P Seligman and Mihaly Csikszentmihalyi, guest editors. Western Journal of Medicine, 174(1), 26-29.

15. Schumacker R. E., Lomax R. G. (2010) A Beginner's Guide to Structural Equation Modeling Third Edition. New York: Routledge. Taylor \& Francis Group, $504 \mathrm{p}$.

16. Seligman M. E. P. (2006) Novaya pozitivnaya psihologiya: nauchnyiy vzglyad na schaste i smyisl zhizni [New positive psychology: a scientific view of happiness and the meaning of life.]. M. Izdatelstvo «Sofiya». 368p.

17. Skripkina T. P. (2000). Psychology of Trust: Guideline for Students of Higher Education Institutions. Moscow: Academiya, 264p. [in Russian]

18. Steiger, J. H. (1994) Factor Analysis in the 1980's and the 1990's: Some Old Debates and Some New Developments. Trends and Perspectives in Empirical Social Research. Ingwer Borg and Peter Ph. Mohler (Eds.). Berlin: Walter de Gruyter, p.201-224 
19. Walsh W. Bruce (2014) Counseling Psychology and Optimal Human Functioning. Vocational Psychology Series. Routledge. Available at

https://books.google.com.ua/books?id=0gAgAAQBAJ\&lpg=PA131\&dq=optimal\%20functioning\&hl=ru\&pg=PA131\# $\mathrm{v}=$ onepage $\& \mathrm{q}=$ optimal $\% 20$ functioning $\& \mathrm{f}=$ false

20. Wulanyani N. M. S. and Vembriaty N. (2018). What factors influence Well-being of Students on Performing Small Group Discussion? J. Phys.: Conf. Ser. 953 (2017) 012004 doi: 10.1088/1742-6596/953/1/012004 